\title{
PRICE BUBBLE IN THE REAL ESTATE MARKET - BEHAVIORAL ASPECTS
}

\author{
Justyna Brzezicka, M.Sc. \\ Faculty of Geodesy and Land Management \\ University of Warmia and Mazury in Olsztyn \\ e-mail: justyna.brzezicka@uwm.edu.pl
}

\author{
Radosław Wisniewski, Assoc. Prof., PhD \\ Faculty of Geodesy and Land Management \\ University of Warmia and Mazury in Olsztyn \\ e-mail:danrad@uwm.edu.pl
}

\begin{abstract}
The article pertains to the topic of speculative price bubbles which arise in the real estate market. The individual parts of the article deal with the connection between the price bubble in the American real estate market and the global economic crisis, defining the concept of a price bubble with regard to the behaviors of market participants, providing a description of the environment generating price bubbles, and systematizing the reasons behind the formation of price bubbles. The analysis of behavioral aspects accompanying the existence of a price bubble is a key issue. The assumed considerations indicate that the housing price bubble could not exist in the real estate market (REM) if its formation was not accompanied by behavioral aspects. These aspects include, among others, giving in to temptations and emotions, limited rationalism, herd behavior, and seeking to make profits in a short amount of time at the expense of long-term negative consequences. The nature of these deliberations is theoretical.
\end{abstract}

Keywords: real estate market, price bubble, behavioral economics, behavioral aspects of the real estate market.

JEL Classification: D03, L85, D79.

Citation: Brzezicka J., Wiśniewski R., 2014, Price bubble in the real estate market - behavioral aspects, Real Estate Management and Valuation, vol. 22, no. 1, pp. 80-93.

DOI: $10.2478 /$ remav-2014-0010.

\section{Introduction}

The global economy is at a time of crisis and the situation in world markets is serious enough to where the crisis has quickly spread to the real sphere. It is widely known that the reason behind the current situation was the turbulence in the American real estate market (REM) and the formation of so called price bubbles. "Many of the world's financial and economic woes since 2008 began with the bursting of the biggest bubble in history. Never before had house prices risen so fast, for so long, in so many countries," (House of... 2011). The formation of price bubbles is not a new problem but, in the light of consequences which we are observing today, their impact on and significance to the world economy is very serious. Many experts are conducting advanced studies focused on factors which bring on the observed behavioral states which can, in general, be classified as risky behaviors. In light of research advances connected with behavioral sciences, it seems justified to ask the question of whether housing price bubbles form in processes which behavior is a synergic factor of.

The aim of the article is to 1) present the phenomenon of price bubbles in the real estate market in light of behaviors exhibited by REM participants, 2) systematize the causes responsible for the 
formation of price bubbles and 3) present the behavioral factors accompanying the existence of a price bubble. At the same time, the research hypothesis that the existence of speculative price bubbles in the real estate market is impossible when not accompanied by behavioral factors was put forward. The deliberations within this work are conducted based on the global crisis environment using the findings of behavioral science.

The deliberations of economists regarding crises (financial, economic, etc.) have extended far beyond the scope of practical application - they have spread to the sphere of deliberations which are theoretical-methodological in nature. Under such circumstances, scientific deliberations should first identify and find the problem, and then present a series of theses, affirmations, descriptions, and instruments which have explanatory power. Literature presents many critical stances regarding the neoclassical approach to economics, along with a simultaneous growing interest in behavioral economics (ETZIONI 2011; RATAJCZAK 2009; WOJTYNA 2011, HOCKUBA 2008; NOGA 2010), especially connected with experiencing a global economic crisis (ALLEN, SNYDER 2009; WYMAN et al. 2011; WILLETT 2010; SZYSZKA 2009a, 2009b, 2011; GLINKA 2011; and many others).

Does this mean that mainstream economics has lost its ability to explain the research topic? The answer is simple and at the same time complex. The simplicity of it lies in the fact that the mainstream (classical) approach, which took many years to develop, has become a formula for theoreticians as well as practitioners. Surely, it has not lost (as a result of, for example, the crisis) its explanatory abilities. On the other hand, the answer is complex because its "explanatory pep" has become weaker in light of new reports regarding the exceptions and imperfections of theoretical and practical solutions which have been known for many years. It is not a coincidence that interest in behavioral sciences has intensified in the times of crisis. Behavioral science provides us with many premises and affirmations, which can more precisely explain the phenomenon of price bubbles forming in the real estate market. Incorporating cognitive and behavioral factors into analyses will enable the explanatory potential of economics to increase, and influence the improvement of the effectiveness of instruments for assessing and verifying the behaviors of REM participants. Behavioral economics is useful and its assumptions work under real conditions, leading to the harmonization of entities' behaviors and their decisions in an imperfect reality, thanks to the mutual cooperation of psychology and economics (ETZIONI 2010; FETCHENHAUER et al. 2011; LESTER, YANG 1995; LUNT 1996; PINGLE 2010; and many others).

The connections between the world economic crisis and the real estate market can be traced back to the beginnings, as turmoil in the American real estate market became the initial cause of the crisis which began in 2007 (WOJTYNA 2011; cited in BOOTLE 2009; KONOPCZAK et al. 2010; BLANCHARD 2009; and many others). Although the existence of speculative bubbles leading to local crises in the REM is not a new phenomenon, the 2008 crises differs from its predecessors by the global impact it had and speed at which it spread (EASZEK et al. 2009). The distinct specifics of processes observed in the American market, which served as an example for describing the course of the phenomenon, were what, in fact, inspired the analyses of price bubbles in the real estate market. Although the macroeconomic aspects of the present situation cannot be overlooked, they are not the main motif of the research and, therefore, certain indispensable simplifications have been allowed.

\section{Price bubble in the real estate market - definition accounting for the behaviors of REM participants}

In literature, a bubble is defined as a "change in the properties of deviations of actual house price growth from its fundamentals, which come from estimates of house price growth as a function of lagged responses to the present value of expected future service flows" (LAI, VAN ORDER 2010, s. 753 cited in KINDLEBERGER, ALIBER 2005), keeping in mind that "In a bubble, a shock to house price growth rates is more self-sustaining (increased momentum) or more volatile than in other periods," (LAI, VAN ORDER 2010, p. 753, cited in KINDLEBERGER, ALIBER 2005). SMITH and SMITH (2006) define the bubble in the REM as a situation in which the market prices of an asset increase significantly above the current value of financial flow expected from that given asset.

Price increases do occur within the realm of the REM. They are natural and justified as long as they occur as a result of factors which ŁASZEK et al. (2009) labeled as "fundamental". These include changes in the procedures (e.g., changes in legislature, recommendations for institutions financing the investments), processes (e.g., changes in demand, changes in liquidity, an increase in investment risk, 
inflation), and structures (e.g., introducing new oversight or financing institutions) of this market. If, however, such factors cannot be identified and prices are shown to increase, the theory calls for the formation of the price bubble phenomenon. Similar mechanisms rule other markets in which bubbles form, such as the financial market (CAGINALP, ILIEVA 2008). Contrary results are presented by GOODMAN and THIBODEAU (2008) who prove that speculative phenomena drive real estate prices up significantly above the level which can be justified by fundamental economic indicators in less than half of the analyzed cities (the trial covered 84 metropolitan areas in the US, with analyses conducted between the years 2000-2005).

The REM price bubble (in the classical understanding) is the occurrence of a rapid increase in prices that is not justified by changes in the market fundamentals (EASZEK et al. 2009). The most graphic explanation of the price bubble phenomenon is presented by HIMMELBERG et al. (2008, p. 1, cited in STIGLITZ 1990) - "If the reason that the price is high today is only because investors believe that the selling price will be high tomorrow - when "fundamental" factors do not seem to justify such a price - then a bubble exists." The phenomenon can be graphically depicted with a chart that shows changes in real estate prices. A model bubble derived from the American market has been presented in figure 1. The long-term increase in the prices of real estate followed by their sudden drop is particularly visible.

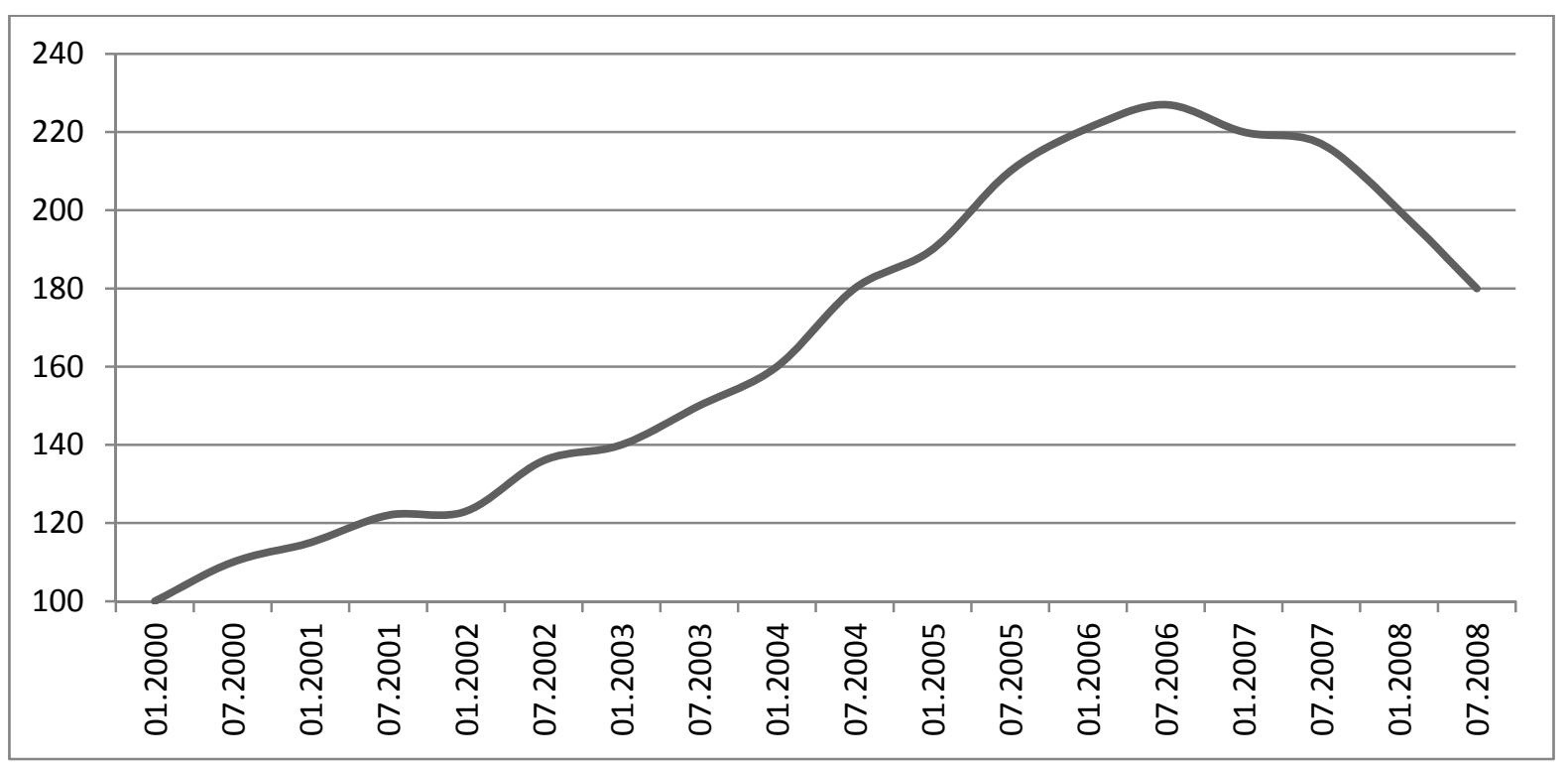

Fig. 1. Dynamics of real estate prices in 20 USA agglomerations between the years 2000-2008 (01.2000 yr. $=100)$, Source: JUROWSKI and ZEGADŁO, 2009, p. 77.

HIMMELBERG, MAYER and SiNAI'S (2008) observations graphically and convincingly illustrate that the formation of a price bubble in the REM is a complex phenomenon. A more in depth analysis, however, indicates that the "human factor" is an element of this complexity, and within it, the behavioral factor. Using the following logic:

Observation 1: lack of grounds behind fundamental changes in the REM system, as proposed by ŁASZEK et al. (2009);

Observation 2: changes in the REM system (in the light of observation 1) do take place however, and in a rather rapid manner;

Conclusion 1: a price bubble is formed in the real estate market;

Conclusion 2: the bubble is induced by non-fundamental factors;

Conclusion 3: the behaviors of participants (behavioral factors) play an important role in the formation of price bubbles in the real estate market system,

the research hypothesis that "the existence of price bubbles in the real estate market is impossible if its formation is not accompanied by environmental factors" can once again be formulated.

Behaviors which are significant in the process of creating a price bubble in the real estate market are mainly overconfidence in one's own judgment of the situation and basing one's decisions on the behaviors of other market participants (herd behavior). Along with the simultaneous aspiration to 
make a profit in a short amount of time, satisfaction of current aspirations, and the occurrence of limited rationalism observed among market entities, the illusion of knowledge and safety along with the excessive optimism of investors can be observed, all of which have led to the formation and swelling of a bubble. In turn, giving in to temptations and emotions, factors dependant on the complexity of human nature, and restricted abilities of perception constitute factors that facilitate the rapidity of the observed changes (see chapter no. 5).

Taking into account these observations regarding the course of the price bubble phenomenon and defining this observable market fact, the first aim of the article (presenting the phenomenon of the price bubble in the real estate market in the light of REM participants) can be considered to have been realized.

\section{The specifics of the bubble forming real estate market}

The issue of price bubble formation is characterized by an individual, collective, and global dimension. This phenomenon ought to be studied and analyzed in the system approach. The real estate market as a system is a realm of relations and dependencies being formed between entities and objects in a multi-dimensional sphere of events (RADZEWICZ et al. 2011). Within the real estate market system (REMS), there are entities and objects, as well as system elements which determine the events that take place within in. The association of the system with the environment is also of importance here, as the REM is "flexibly contained within the entirety of the social-economic system (...) and is strongly connected with it" (BRYX 2008, p. 89). This explains the great impact of the world economic crisis on the real estate market. Economic as well as legal, political, and social conditions have a large influence on real estate market participants and their decisions.

The real estate market in the system approach constitutes the background for further contemplations regarding the specifics of the real estate market generating speculative price bubbles. Instability, changeability, and the dynamics of this system make analyzing the state of the market and identifying developmental barriers difficult and, at the same time, make it impossible to notice the first disquieting signals that indicate the existence of a price bubble. The following components and features of the real estate market system are especially significant to the process of forming a speculative bubble: 1) the specifics of real estate as an object of investment, 2) capital intensity which is reflected in the mortgage sector, 3) uncertainty, and 4) the connection with economic cycles.

Firstly - real estate as an object of investment. The specifics of real estate as a target of investment encourage people to take action, owing to the long period of exploitation and protection from inflation. When the macroeconomic situation is favorable, real estate becomes a profitable form of investment, and this very conviction (often not supported by fundamental factors - and so connected with behavioral factors) causes a further escalation of prices. Moreover, "the value of real estate increases because of the fact that, along with the increasing demand for real estate (the human population continues to grow), the supply (the amount of available property doesn't increase) remains the same (or quasi same - author's annotation), or even decreases", thus, there is the deeply rooted conviction that, "real money lies in real estate" (FIJOR 2004, p. 4). Equally important is the feature of the REM connected with the necessity to consistently realize investment undertakings. The specifics of REM make it is more cost-effective, even in the light of an unprofitable investment, to go through with the investment process than to terminate it. This is supported by the strategy of smaller losses. In such situations, behavioral factors are smoothly connected with fundamental factors.

Secondly - capital intensity. The specifics of the REM, especially high capital intensity and low investment liquidity, increase the role of the mortgage sector (JóźWICKI 2009). The role of the mortgage sector in the structures of the real estate market stems from the growing significance of financing investments through loans. The revival of the mortgage sector is often caused by the development of the housing real estate market (the demand for housing, e.g., in Poland, has still not been met), more relaxed loan policies, and the flexibility of granting loans in a foreign currency (KOWALCZYK 2009). It should also be added, that a properly functioning mortgage sector is, in itself, a critical link connecting the real estate market system. Thanks to the services it provides, the mortgage sector has a stabilizing effect on processes taking place in the REM and necessitates employing certain standards, such as those connected with assessing the level of investment risk.

As shown by the analysis of the events which have occurred throughout the world over the past decade, it takes repeated abuse and gaps in the law to lead to disquieting changes and the formation 
of price phenomena. When investments are financed predominantly from external sources, the increased importance of the mortgage wallet facilitates the development of the market itself, and the transformation of potential demand into effective demand, all the while satisfying basic housing needs and ensuring relative stability and favorable conditions in the future (PóŁTORAK 2006). Appropriate financial instruments allow some of the investment restrictions to be lowered or even eliminated, thanks to which the market itself can be more liquid (PÓŁTORAK 2008).

Thirdly - uncertainty. The key role of uncertainty in the process of forming bubbles results from its endemic nature in the housing market. "Uncertainty dictates all processes occurring in the real estate market realm. It refers to the level of individual, group and collective events, and influences the object, entity, and system," (RADZEWICZ et al. 2011, p. 2). It constitutes an element of the market game dependent on random factors, and "is a background for this game, and at the same time, a factor destabilizing it which, in a more or less deliberate fashion, attempts to influence the decisions being made. Uncertainty, as a factor and a phenomenon, allows some investors to make profits, is indifferent to others, and for others still, leads to losses," (RADZEWICZ, WIŚNIEWSKI 2011, p. 47). Besides accurate decisions, it also generates bad ones leading to irreversible changes (BADDELEY 2005), since the result of an investor's operations depends on identifying the current and future fields of risk and uncertainty (OSTROWSKA 2002). Uncertainty, financial restrictions and the irreversibility of decisions cause variation in the housing market at the microeconomic level. Such instability at the microeconomic level affects buyers, sellers, creditors, and borrowers, as well as the mutual interactions between them, which increases microeconomic instability and explains the lack of complete rationalism in behaviors (BADDELEY 2005). "In a world of uncertainty, imperfect information and irreversible decision-making, speculation and information acquisition will generate bubbles, herding and frenzies in housing demand," (BADDELEY 2005, p. 1). All of these factors make the credible and practical prediction of market changes difficult. "Macroeconomic forecasts come in two varieties: statistical objects produced by mechanical models, and economic objects produced by human beings," (LAMONT 2002, p. 265); both methods facilitate numerous mistakes and manipulations.

Lastly, there is the connection with economic cycles. The connection of speculative bubbles with economic cycles is also of importanc; in the recovery stage, developers are more prone to taking on new investments, whereas the opposite tendency can be observed during the recession phase (KUCHARSKA-STASIAK 2006). "The history of crises and cycles reveals that progress is not permanent and that recession must follow each period of economic growth - that is how economic cycles function," (KANAK 2009, p. 45). Despite numerous differences, it is in these terms that the anatomy of a speculative bubble resembles the macro- and microeconomic changes that take place within an economic cycle. Likewise, the plurality of factors and dependencies which occur in both of these phenomena is a similar feature. "Business cycles simultaneously depend on a combination of multiple factors, the mutual relationships of which determine the final outcome of the economy as a whole," (GOŁĄBESKA 2010, p. 24).

\section{Reasons behind the formation of bubbles - system approach}

When systemizing the reasons behind the existence of speculative price bubbles, the factors should be divided into endogenous and exogenous ones. This division is not theoretical but rather conditioned by the specifics of the market as well as of factors shaping the phenomena of price bubbles. Causes of an exogenous nature can be grouped into three main categories:

1) Causes of a institutional-legal (WOJTYNA 2011) or political (BADDELEY 2005; TSAI and PENG 2011) nature, including the liberal stance of national governments towards the banking sector (PNIEWSKA 2011; GWIAZDOWSKI 2012; ŁASZEK et al. 2009),

2) Macroeconomic conditions (LEUNG 2004; LEUNG and QUIGLEY 2007), i.e., low interest rates which encourage speculation (ŁASZEK et al. 2009; AGNELLO and SCHUKNECHT 2011; OSTASZEWSKI 2010), prolonged economic growth (HOCKUBA 2008), easy access to investment funds (ŁASZEK et al. 2009; BRUECKNER et al. 2012), an adequate (low) level of inflation (TAIPALUS 2006), international financial liquidity (AGNELLO and SCHUKNECHT 2011), increase of financial reserves and surpluses in current accounts which, along with a slower increase in demand than income, led to higher savings and next their transfer into the real estate sector (WOJTYNA 2011),

3) Causes, the source of which can be found in the risk and the uncertainty of markets (BADDELEY 2005), occurring at the global and local level and perceptible, among others, due to the unreliability of rating agencies (STOLIŃSKA 2008). The opinions of rating agencies had 
a significant influence on shaping the demand for debt securities. The assessments and principles they present are cohesive in nature and they therefore constitute a source of information which is unifying and presumed as unbiased (RENIGIER-BIŁOZOR, WIŚNIEWSKI 2012). Obtaining a high rating means a high level of safety and hence, the increased interest of investors (KALASIŃSKA 2011). Late and inaccurate assessments of rating agencies (constituting an important component of the market game) influenced the trust of investors, who overrated the opinions put out by these agencies.

The systematics of endogenous factors, on the other hand, is possible by dividing them into three levels:

1) Level I (entity level):

- the common expectations of business entities connected with assets (Łaszek et al. 2009; ADAMS, FÜSS 2010), the perspective of making a profit in a short period of time (EASZEK et al. 2009). The increased expectations of households motivated by the perspective of quick and unremitting growth, an escalation of demand, and the cranking up of prices (EASZEK et al 2009) facilitated further investments which caused the price bubble to swell and ultimately burst when money was no longer readily available (HOCKUBA 2008);

- behavioral and cognitive factors (SZYSZKA 2009a, 2009b; GLINKA 2011), including the effects of herd behavior, anchoring, competition, etc.;

- infringements connected with the proper supervision of owners.

2) Level II (asset level):

- high returns on real estate (PNIEWSKA 2011);

- increased long-term real estate appreciation rates. The prices of houses and flats are sensitive to price growth rates at already low rates, and their sensitivity increases when the growth rate of real estate prices is high for a long period of time (HIMMELBERG et al. 2008). In the years 1999-2005, the yearly increase in house prices noted by the Federal Housing Financing Agency remained constant at a level of about $8.4 \%$ per year, and calculated using CaseShiller Home Price Indices, amounted to as much as $11.3 \%$ per year (DIEWERT et al. 2009, p. 156), whereas the real growth (in the years 1990-2005) was found to be at a level of $6.5 \%$ (GOODMAN, THIBODEAU 2008, p. 117);

- increased demand for very good locations along with the limited supply of them; inflexible supply in the housing sector (GLAESER et al. 2008).

3) Level III (system level):

- increased supply of and demand for high-risk mortgages (KONOPCZAK et al. 2010; COLEMAN et al. 2008) and the formation of investment instruments utilizing "toxic" mortgages. High return rates on real estate along with favorable macroeconomic conditions led to a higher demand for subprime and NINJA mortgages offered, among others, to entities with limited financial solvency (PNIEWSKA 2011). Favorable price expectations alleviated the concerns of creditors, increasing their readiness to grant mortgages even to risky creditees. Price bubbles in the American real estate market formed most often after the year 2003 "in a relatively short period of time, as a consequence of positive, seemingly incidental shocks, associated with the strong growth in the high-risk loan market and decline of short-term interest rates," (LAI and VAN ORDER 2010, p. 753);

- disproportions in the house ownership and rental markets (a less appealing house rental market when compared to ownership) and a state of imbalance in the residential housing development sector (DIEWERT et al. 2009);

- risk and/or uncertainty of the real estate market and investments (BADDELEY 2005);

- lack or limited activity of institutions responsible for the indirect oversight of ownership;

- "excessive optimism" in decision-making processes accompanied by limited access to information or lack thereof.

One should be reminded that price bubbles form when the prices of real estate are not validated by fundamental factors. Not every dynamic increase in the prices of assets leads to the formation of a price bubble because supply and demand can be connected with long-term demographic trends, building costs, the availability of building land, the level of interest rates and the accessibility to loans (EASZEK et al. 2009). In the light of changes taking place, fundamental factors appear to have little significance in the bubble formation process (COLEMAN et al. 2008). A connection between speculative 
bubbles (on the American real estate market) and the housing rental sector has also not been observed (LAI, VAN ORDER 2010), and it should be noted that in developed markets, which the American market constitutes an example of, the rental market is a substitution market for the ownership market, (ŁASZEK et al. 2009) as well as serving a market balancing function (DIEWERT et al. 2009).

The deliberations undertaken in the article unanimously indicate that the real estate market, up until now viewed as a secure and passive place for realizing profits, has suddenly become an active player. The change of state, from passive to active, and the above indicated structural problems have led to a heavy collapse and crisis with grave consequences. Because this crisis affected one of the world's largest economies, it has spread very quickly and continues to last until this very day. In the light of these analyses, the second aim of the article regarding the systematics of causes behind the formation of price bubbles in the real estate market can be considered to have been met.

\section{Behavioral aspect}

A key issue in the bubble formation process in the real estate market is the question regarding the significance and inevitability of behavioral aspects (the article thesis). Would the speculative bubble have formed without the contribution of behavioral factors which shape an entity's decisions? Behavioral factors, similarly to the crises environment, are also especially evident in the sphere of the real estate market surrounding the bubble, and this sphere facilitates their occurrence even more. Behavioral sciences appear on a double-track here: 1) they can be analyzed through the prism of the entities' behaviors (individual, herd, etc.) and 2) through the prism of the S-R (stimulus - reaction, $\mathrm{KOCH} 2002$ ) chain, the first approach drawing on behavioral economics, with the second based more on early psychological behaviorism.

The conducted analyses indicate that behavioral factors, regardless of how they are referred to (cognitive, psychological, or other forms of behaviorism), are an essential element to the formation of the price bubble phenomenon in real estate markets. "The human factor" is necessary where unlearned behaviors are concerned. This necessity has many levels of meaning. Necessary understood as: an obligatory component of decisions (in theory, it is always present), the actual and realistic impact of our behaviors on decision-making processes (how we want to behave in given situations), the creative factor (without it, decisions would only be a compilation of machine-like instructions) which determines our own actions as well as those of others (we frequently realize our "desires", which are often detached from reality, at the spurt of the moment and without accounting for how they will affect other REM participants). If fundamental and learned factors can be treated as basic components used to construct the decision-making process, then behavioral factors enrich and make the process more dynamic, giving it a nature more similar to the realities which occur in the "normal" and actual sphere of decision-making. On the other hand, these factors are the reason behind the creation of risk and uncertainty. The dynamic, risk and uncertainty inducing nature prescribed to behavioral factors is becoming a distinctive sublimator in the REM realm. Although it is impossible to list the whole range of behavioral aspects associated with the formation of speculative bubbles in the REM, it is worth to draw attention to at least some of them, i.e.: restricted rationalism, shortsightedness, herd behaviors, giving in to emotions and temptations.

Firstly - rationalism. The basic assumption regarding the rationalism of entities requires rejecting the criteria of full rationality and accepting the possibility of there being certain restrictions (VRIEND 1996). Making investment decisions based on one's own cognitive possibilities and simplified mechanisms, known as heuristic, is an expression of limited rationalism in the speculative bubble formation process (SIMON 1955). The observation of reality from the level of an individual and limitations of human perception result in the possibility of mistakes being made by entities when attempting to reach the best decision. In uncertain and seemingly problem-free situations, it is especially easy to intuitionally make decisions leading to cognitive mistakes (so called inclinations) which restrict the ability to behave in a logical and informed manner (KRASKA-BIENKKOWSKA 1997). Moreover, when making decisions people don't seek out solutions which maximize profit but rather those that fulfill their current aspirations (ZALEŚKIEWICZ 2011). We must also not ignore aspects connected with overrating the homo oeconomicus (HO) model, which is often used to describe the attitudes of market entities. The HO model is not applicable in the uncertain realm of the REMS and anywhere that the actual motivations behind human behavior are activated. That is why it is more functional to propagate the real human silhouette, which draws a lot from the scientific output of psychology, sociology and other fields of studies, revealing traits closer to those of a human than a 
cyborg (BRZEZICKA, WIŚNIEWSKI 2014).

Secondly, when trying to explain the behaviors of market participants, attention should be drawn to looking to make a profit in a short amount of time and ignoring the long-term consequences of decisions (RATAJCZAK 2009). This assumption is reflected in the generally accepted way of thinking - if favorable market conditions exist today, continue to invest (as the saying "make hay while the sun shines" goes). This may be read as an unwillingness to suffer a loss, understood as not taking advantage of opportunities when the economic cycle is at a downturn. Market participants rarely adhere to the principle of delayed gratification. By maximizing advantages at the moment the decision is being made, they satisfy their own individualized needs and, at the same time, "benefit from the given moment" without accounting for the realities of a long-term perspective. They themselves induce a whole range of behaviors which constitute the base for creating a wave of real estate price increases and the formation of a price bubble. The fact that decision-makers are more sensitive to losses than gains (KAHNEMAN and TVERSKY 1979) somewhat justifies the short-sightedness of actions taken by them. Moreover, mortgages taken out to purchase real estate are, as a rule, long-term obligations, while credit-rating agencies used statistical data based on a relatively short period of time which decision-makers, nevertheless, deemed credible (SZYSZKA 2009a).

Thirdly, herd behaviors, that is actions based on the observations of how other members of a population behave, are not indifferent to the real estate market. Their importance depends on the cumulative factor (FELDMAN 2010) because an action undertaken by a single investor does not influence market prices. "If investors did not act in a collective manner and simultaneously make the same mistakes of a psychological nature their actions would, by and large, neutralize one another and the market would remain effective," (SZYSZKA 2009b, p. 84). The occurrence of the herd effect results in large fluctuations and prices do not provide complete information about the market (TEDESCHI et al. 2012). The effects of copying ("others are buying - so will I"), being guided by a false sense of security which leads to excessive optimism when assessing many uncertain events (Tyszka 1999), and the effect of feedback, that is decisions regarding the purchase and sales based on observing the relationship between the behaviors of other market participants and the level of prices (buying with the expectation of further increase - if others are buying, they are surely counting on prices continuing to rise) are of key importance here (SZYSZKA 2009b). The earlier described satisfaction of one's own individualized needs to maximize gain is not in the least antagonistic to herd behaviors. Such behaviors are further intensified by the pressure of an entity who wishes to achieve success at all cost. Interestingly enough, herd behaviors are not only characteristic of individual investors, but also of experienced prognostics and economists of all ages, operating on various markets (ASHIYA, DOI 2001).

Lastly, emotions and temptations are an inevitable part of investing. On one hand, it is selfconfidence and greed (GWIAZDOWSKI 2012), on the other - excessive trust in the system and the optimism of investors (ŚWIERKOCKI 2011) that blow up prices. Enthusiasm during times of economic boom effectively influences the formation of price bubbles (ADAMS, FÜsS 2010), and the emotional arousal of market participants is an additional motor propelling actions characterized by limited rationalism. A market participant, oftentimes an amateur lacking basic knowledge regarding the processes that take place within the market, observes market trends and invests with the intention of making a profit. His or her motivation lies in anticipating further price increases of assets. This leads to the conviction of infallibility and overestimation of one's abilities and knowledge, and consequently, to living in the illusion of possessing the ability to accurately predicts price changes in the market (CZERWONKA, GORLEWSKI 2012). "People in general, are overly confident in their knowledge and abilities. They have a tendency to overestimate the scope of their knowledge, underestimate risk, and put too much trust in their own ability to control the processes taking place, (...) they become overly confident, especially if they had previously achieved quick success in a field that was new to them," (ZIELONKA 2003, p.19). The illusion of knowledge also occurs as a result of information overload, which does not allow for the information to be amply processed, and creates a false feeling of being fully informed (PAŁKA 2004, p. 37). Moreover, there is the problem of a person's limited capacity of storing information; even with excellent access to data, a decision can turn out to be incorrect, because people reduce excess information and analyze it only selectively (TYSZKA 2010). This observation may explain the erroneous actions of entities contributing to the real estate market.

Each of the above-described behavioral factors can be understood as a reaction to the existing stimuli derived from the REMS or its surroundings. With the proper physiognomy of market 
structures, some signals become particularly evident and encourage the entities to invest; here, behavioral factors have a constitutive nature. They are essential to the process of forming speculative bubbles given that, when joined together, they have a synergic effect on the REMS and play a role in connecting the individual levels. The speculative bubble could not exist without the desire to possess, which is expressed by making investments even in extreme cases of financial insolvency.

The present analyses have allowed for the third aim of the article to be realized and the thesis regarding the integrity of behavioral aspects in the bubble formation process to be confirmed. The above review of behaviors should not leave doubt as to the growing importance of behavioral sciences in regard to the functioning of markets, including the real estate market. These issues had already been addressed earlier (BRZEZICKA, WIŚNIEWSKI 2012; 2013) and when faced with the increasing instability of market structures, constitute an alternative explanation of behaviors which had been regarded as peculiar by mainstream economics.

\section{Discussion and conclusions}

As early as the verge of the 21st century, unsettling tendencies to deregulate the world monetary and capital market were observed in the light of progressing globalization intensifying the instability of the system, financial shocks, and the continuous threat of the collapse of financial markets (ŁUKASZEWICZ 2001, cited in THUROW 1996; SORDI, VERCELLI 2006). These doubts were warranted in the face of the global economic crisis which originated in the American real estate market.

Although often marginalized or unnoticed, behavioral factors, with extra consideration given to individual and social psychology, play a huge role in the bubble formation process. The standpoints of some of the greatest behavioral economists regarding the occurrence of an economic crisis and speculative bubbles on the American real estate market should be stressed. THALER and SUNSTEIN (2012, p. 292) prove that "the process of social infection had a very strong influence on people. This belief created completely unrealistic projections, with tangible consequences of buying houses and choosing to take out mortgages." AKERLOF and SHILLER (2010, p. 196) emphasize that "everyone was investing, despite the fact that no rational argumentation whatsoever regarding the possibilities which such investment offers existed." As stated in historical sources (THALER, SUNSTEIN 2012, p. 292), house prices in the US during the years 1997-2004 jumped spectacularly, while in the public's opinion, the deeply rooted belief that "the nature of house prices is to rise over time" (THALER, SUNSTEIN 2012, p. 292) incurred certain repercussions and contributed to developing attitudes of openness to investments. These attitudes have become the foundation for forming a bubble by the REMS and their increase in strength and dynamic spread at the entity level of the system clinched the process and determined its rate, on top of inducing a wave which affected the remaining levels of the real estate market system and its surroundings. Thanks to this observation, the inherent nature of behavioral factors in the real estate market system as well as in the process of forming a speculative bubble becomes especially evident.

The specifics of the REM and complexity of its structures, natural fluctuations which it is subject to and multiple aspects of relationships occurring in the REMS and its environment make it difficult to analyze and identify abnormalities in their early phases. The phenomenon of the formation of speculative bubbles should not be surprising in the light of REM analysis when accounting for uncertainty and the limited rationalism of REM participants.

The speculative bubble is interference in the real estate market system. Its nature is most often pejorative and it can be understood as a cumulative mistake in the actions taken by market participants, the inadequate oversight of market processes, and the faulty functioning of the internal and external market structures as displayed by the dynamic increase in prices to a level which exceeds borderline efficiency, occasionally leading to the collapse of the system.

Bubbles form when the earlier mentioned exogenous and endogenous factors associate, accompanied by the spontaneous reaction of entities expressed by attitudes, which are described as behavioral. The simultaneous (or sequential) occurrence of the above stated factors, including behavioral factors, is a condition that must be met. If not for the foolishness of investors and shortsightedness of institutions (which are run by people and thus, behaviors), the speculative bubble would not exist. It is from such institutions and overseeing bodies that individual investors should receive assistance in assessing risk and finding one's way through the complex arrangement of financial tools. Over the last decade, it was these very institutions that have let their people down. By increasing the urge to make large profits in a short amount of time, they have become the catalyst of 
the "heated" real estate market system. Similarly, the mortgage sector, intrinsically the carrier of development, plagued by abuse for which the incompetence of people was responsible, has led the real estate sector to a state of crisis.

Although the speculative bubble can constitute the reason behind the crisis and unfavorable changes per se, it can also be treated as the effect of crisis situations. Before the formation of a speculative bubble can take place, a specific set of events, often regarded as positive (e.g., long-term economic growth), must occur. The absence of prevention and often limited intervention lead to speculative actions and adverse consequences. Ex post analyses have revealed that benefits are often superficial (maximized short-term profits are not real profits) and in reality contribute to the system's downfall (a paradox of growth).

The essential "collectiveness" of individual entities' reactions to changes in the system is yet another paradox of the speculative bubble. On one hand, it is this mass reaction and large scale of the phenomenon that enable it to take place; on the other hand, it is the market participants who cause such adverse consequences. In the light of the observed mass effects, individual actions only amplify the phenomenon of "throwing oneself" into a whirlpool of investing. Collectiveness can be analyzed as a stimulus as well as in terms of reactions to the changes which have taken place. Undoubtedly, it was the scale (collectiveness) of the phenomenon in 2008 that became the beginning of the end of the boom that led to the spectacular worldwide economic crisis.

The real estate market, which used to be the flywheel of profits, has suddenly become a brake and lead to large-scale losses affecting just about every investor. Investors who were observing the stampeding real estate market through rose-colored glasses (in bright sunlight) did not notice that dawn had come and that the days of profit-making had turned into nights of losses (those rosecolored glasses only made it worse). Rose-colored glasses in the above example serve as a synonym of behavioral acts. Sober and rational economic assessment should have caused REM participants to quickly remove these glasses. Then, they would have noticed the fundamental bases (the oversupply of "bad" loans, the irrational (not supported by purchasing power) level of demand, or the overly abundant supply of real estate as a result of overheating in the housing development and building sectors); they would have noticed that profits had died down and losses had become the new reality.

The attitudes of market participants, seeking out lucrative investments and short-term benefits at the cost of long-term losses, have key importance to the formation of bubbles in the real estate market. "It was the limited rationalism of people and their tendency to give in to temptations which brought on today's crisis," (HOCKUBA 2008). Professors THALER and SUNSTEIN (2012, p. 295) express their standpoint even more clearly, summarizing their reflections on the real estate sector and mortgages as well as the worldwide crisis, and leaving no doubt as to the reason behind its occurrence: "Greed and corruption contributed to bringing on the crisis, but it was mere human weakness that played the key role. In the future, we will not protect ourselves from a crisis if we are to only fulminate greed, corruption and general evil, not looking in the mirror and not trying to understand the potential damaging effects of limited rationalism, problems with self-control, and social influences."

Various acts of REM participants, which together can be referred to as "behavioral", were (and probably still are) a synergistic causative factor. They had an indirect as well as direct effect. Market participants made more conscious or less conscious decisions in the "behavioral environment". They created this environment themselves and later (thanks to their own individual actions) changed it, to ultimately suffer the consequences of such actions. The creators (of the behavioral environment) faced a phenomenon which, even having created it themselves, they did not understand. This led to a state where the behavioral environment conditioned the entities and not the other way around. The presented state of events ought to be explained. A posteriori identification in behavioral science allows us to draw conclusions which can later be used a priori.

Two years after the worst crisis since the Great Depression of the nineteen thirties, "The Economist" announced: "There are two things everyone knows about American economic recoveries. The first is that the housing sector traditionally leads the economy out of recession. The second is that there is no chance of the housing sector leading the present economy anywhere, except deeper into the mire," (Housing and... 2011). In the general context, a third point should be added to these conclusions. "Thirdly, the real estate market has ceased to be a passive market of goods (a junior market) and become an active investment market which can either lead the economy of any country out of a crisis or bring it to the verge of collapse." One can only hope that this graphic conclusion, which emphasizes 
the unparalleled nature of changes taking place, will serve as a good lesson, the results of which will be the increased responsibility of entities, societies, and institutions, and that it will allow us to avoid similar experiences in the future.

\section{References}

ADAMS Z., FÜSS R., 2010, Macroeconomic determinants of international housing markets, Journal of Housing Economics, No. 19(1), pp. 38-50.

AGNELLO L., SCHUKNECHT L., 2011, Booms and busts in housing markets: Determinants and implications, Journal of Housing Economics, No. 20 (3), pp. 171-190.

AKERLOF G.A., SHILlER R.J., 2010, Zwierzęce instynkty. Czy ludzka psychika napędza globalna gospodarkę i jaki to ma wptyw na przemiany światowego kapitalizmu (Animal instincts. Does human psychology fuel the global economy: effect on the transformations of global capitalism)?, Studio Emka, Warszawa.

ALLEN R.E., SNYDER D., 2009, New thinking on the financial crisis, Critical perspectives on international business, No. 5(1), pp. 36-55.

AshiYa M., DoI T., 2001, Herd behavior of Japanese economists, Journal of Economic Behavior \& Organization, No. 46(3), pp. 343-346.

BADDELEY M., 2005, Housing Bubbles, Herds and Frenzies: Evidence from British Housing Markets, Cambridge Centre for Economic and Public Policy Brief, No. 02/05.

BlanChard O., 2009, The Crisis: Basic Mechanisms, and Appropriate Policies, IMF Working Paper, $\mathrm{WP} / 09 / 80$.

BOoTLE R., 2009, The trouble with markets. Saving Capitalism itself, Nicholas Berkley Publishing, London.

BRUECKNER J.K., CALEM P.S., NAKAMURA L.I., 2012, Subprime mortgages and the housing bubble, Journal of Urban Economics, No. 71(2), pp. 230-243.

BRZEZICKA J., WISNIEWSKI R., 2012, Behawioralne aspekty rynku nieruchomości (Behavioral aspects of the real estate market), Studia i Materiały Towarzystwa Naukowego Nieruchomosci, No. 20(2), pp. 21-31.

BRZEZICKA J., WISNIEWSKI R., 2013, Ekonomia behawioralna a rynek nieruchomości - teoria i praktyka (Behavioral economics and real estate market theory and empiricism), Psychologia ekonomiczna, No 3, pp. 6-18.

BRZEZICKA J. WISNIEWSKI R., 2014, Homo oeconomicus and Behavioral Economics, unpublished results, under review in: Contemporary Economics.

BRYX M., 2008, Rynek nieruchomości: system i funkcjonowanie (The real estate market: system and functioning of), Poltext, Warszawa.

CAGinalP G., ILIEVA V., 2008, The dynamics of trader motivations in asset bubbles, Journal of Economic Behavior \& Organization, No. 66(3-4), pp. 641-656.

Coleman IV M., LACour-LitTle M., VANDELl K.D., 2008, Subprime Lending and the Housing Bubble: Tail Wags Dog?, Journal of Housing Economics, No. 17(4), pp. 272-290.

CZERWONKA M., GORLEWSKI B., 2012, Finanse behawioralne. Zachowania inwestorów i rynku (Behavioral finances: behaviors of investors and the market), Oficyna Wydawnicza SGH w Warszawie, Warszawa.

DiEWERT, W.E., NAKAMURA, A.O., NAKAMURA, L.I., 2009, The housing bubble and a new approach to accounting for housing in a CPI, Journal of Housing Economics, No. 18(3), pp. 156-171.

ETZIONI A., 2010, Behavioral economics: A methodological note, Journal of Economic Psychology, No. 31(1), pp. 51-54.

ETZIONI A., 2011, Behavioral Economics: Toward a New Paradigm, American Behavioral Scientist, No. $55(8)$.

FELDMAN T., 2010, Portfolio manager behavior and global financial crises, Journal of Economic Behavior \& Organization, No. 75(2), pp. 192-202.

Fetchenhauer D., AZAR O.H., ANTONides G., DunNing D., Frank R.H., LeA S., Ölander F., 2011, Monozygotic twins or unrelated stepchildren? On the relationship between economic psychology and behavioral economics, Journal of Economic Psychology, No. 33(3), pp. 695-699.

FIJOR J. M., 2004, Prawdziwe pieniadze sa w nieruchomościach (Real money lies in real estate), Finansowanie nieruchomości, Gazeta Bankowa - dodatek No. 2, 4-7.

GlAeSER E.L., GYOURKO J., SAIZ A., 2008, Housing supply and housing bubbles, Journal of Urban Economics, No. 64(2), pp. 198-217.

GLINKA K., 2011, Behawioralne aspekty decyzji inwestycyjnych a otoczenie instytucjonalne rynków finansowych (Behavioral aspects of investment decisions and the institutional surroundings of financial markets). In: Wojtyna A. (Ed.), Kryzys finansowy i jego skutki dla krajów na średnim poziomie 
rozwoju. PWE, Warszawa, pp. 141-164.

GoŁĄBESKA E., 2010, Cykle koniunkturalne na rynku nieruchomości (Economic cycles in the real estate market), Świat nieruchomości, No. 74, pp. 24-27.

GOODMAN A.C., THIBODEAU T. G., 2008, Where are the speculative bubbles in US housing markets? Journal of Housing Economics, No. 17(2), pp. 117-137.

GWIAZDOWSKI R., 2012, A nie mówitem? Dlaczego nastąił kryzys i jak najszybciej z niego wyjść? (Didn't I tell you? Why the crisis occurred and the quickest way out), Wydawnictwo Prohibita, Warszawa.

House of horrors, part 2, 2011, The Economist, No. 26, November.

Housing and the economy, rising from ruins, 2011, The Economist, No. 5, November.

Himmelberg C., MAYer C., SinAi T., 2008, Assessing High House Prices: Bubbles, Fundamentals, and Misperceptions, Federal Reserve Bank of New York Staff Reports.

HocKUBA Z., 2008, Pożegnanie z homo oeconomicus (A farewell to homo oeconomicus), Rzeczpospolita, No. 23, December.

JóźWICKI R., 2009, Analiza aktywów wybranych instytucji finansowych na rynku nieruchomości w Polsce (Asset analysis of selected financial institutions in the Polish real estate market), Prace Naukowe Uniwersytetu Ekonomicznego we Wrocławiu, No. 60, pp. 131-140.

JUROWSKI A., ZEGADŁO P., 2009, Geneza $i$ dotychczasowy przebieg globalnego kryzysu finansowego (The global financial crisis: genesis and course of), Bezpieczny bank, No. 1(38), pp. 75-110.

KAHNEMAN D., TVERSKY A., 1979, Prospect theory: An analysis of Decision under risk, Econometrica, No. 47(2), pp. 263-292.

KALASIŃSKA M., 2011, Ryzyko w procesie sekurytyzacji (Risk in the securitization process), Finansowanie nieruchomości, No. 26(01), pp. 12-21.

KANAK E., 2009, Cykle koniunkturalne na rynku nieruchomości (Economic cycles in the real estate market), Świat nieruchomości, No. 69, pp. 40-45.

KAUFMAN B.E., 1999, Emotional arousal as a source of bounded rationality, Journal of Economic Behavior \& Organization, No. 38(2), pp. 135-144.

Kindleberger C., Aliber R., 2005, Manias, Panics and Crashes: A History of Financial Crises, Wiley Hoboken, NJ.

KOCH S., 2002, Psychologia wobec pojawiajacych sie koncepcji wiedzy (Psychology in view of the emerging concepts of knowledge), In: Wann T.W. (Eds.), Behawioryzm i fenomenologia: różne ujęcia współczesnej psychologii, Wydawnictwo Uniwersytetu Jagiellońskiego, Kraków, pp. 11-57.

KONOPCZAK M., SIERADZKI R., WIERNICKI M., 2010, Kryzys na światowych rynkach finansowych - wplyw na rynek finansowy w Polsce oraz implikacje dla sektora realnego (The crisis in global financial markets - the impact on the financial market in Poland, and the implications for the real sector), Bank i kredyt, No. 41(6), pp. 45-70.

KOWALCZYK P., 2009, Analiza wybranych metod finansowania nieruchomości (Financing real estate: the analysis of select methods), Prace Naukowe Uniwersytetu Ekonomicznego we Wrocławiu, No. 60, pp. 203-213.

KRASKA-BieŃKOWSKA M., 1997, Procesy poznawcze (Cognitive processes), Zeszyty Naukowe Uniwersytetu Szczecińskiego, No. 204, pp. 181-199.

KUCHARSKA-STASIAK E., 2006, Nieruchomość w gospodarce rynkowej (Real estate in the market economy), PWN, Warszawa.

LAI R.N., VAn ORDer R.A., 2010, Momentum and House Price Growth in the United States: Anatomy of a Bubble, Real Estate Economics, No. 38(4), pp. 753-773.

LAMONT O.A., 2002, Macroeconomic forecasts and microeconomic forecasters, Journal of Economic Behavior \& Organization, No. 48(3), pp. 265-280.

LeUNG C., 2004, Macroeconomics and housing: a review of the literature, Journal of Housing Economics, No. 13(4), pp. 249-267.

LEUNG C.K.Y., QUIGLEY J.M., 2007, Special issue on macroeconomics, regulation, and housing introduction, Journal of Housing Economicsm, No. 16(2), pp. 99-101.

LeSTER D., YANG B., 1995, New Directions for Economics, The Journal of Socio-Economics, 24(3), 433-446.

LUNT P., 1996, Rethinking the relationship between economics and psychology, Journal of Economic Psychology, No. 17(2), pp. 275-285.

ŁASZEK J., AUGUSTYNIAK H., WIDŁAK M., 2009, House price bubbles on the major polish housing markets, Working paper presented at the Annual Conference of the European Network for Housing 
Research, Prague.

ŁUKASZEWICZ A., 2001, Dylematy ekonomiczne przełomu stuleci (Economic dilemmas turn of the century), Key Text, Warszawa.

NoGA M., 2010, Czy wspótczesna ekonomia przewidzi światowa recesję? (Will modern-day economics foresee a world recession?), [http://www.obserwatorfinansowy.pl/forma/debata/czy-wspolczesnaekonomia-przewiodzi-swiatowa-recesje/, no10, February], accesed 2 Jan. 2013

OSTASZEWSKI J., 2010, Finanse (Finances), wyd. V, Difin, Warszawa.

OSTROWSKA E., 2002, Ryzyko projektów inwestycyjnych (Investment project risk), PWE, Warszawa.

PAŁKA T., 2004, Finanse behawioralne: moda czy konieczność? (Behavioral finances: trend or necessity?), Gazeta Bankowa, No. 15, pp. 36-37.

PINGLE M., 2010, Looking under the hood: Exploring assumptions and finding behavioral economics, Journal of Economic Behavior \& Organization, No. 73(1), pp. 73-76.

PNIEWSKA K., 2011, Wptyw globalnego kryzysu finansowego na polski sektor finansowy (The influence of the global financial crisis on the Polish financial sector), In: Przybylska-Kapuścinska W. (Ed.). Reakcje rynku na kryzys finansowy (Market responses to the financial crisis), CeDeWu, Warszawa, pp. 3140.

PÓŁTORAK B., 2006, Ceny na rynku nieruchomości a kredytowanie hipoteczne (Real estate market prices and mortgaging), Prace Naukowe Akademii Ekonomicznej we Wrocławiu, No. 1119, pp. 238-249.

PÓŁTORAK B., 2008, Finansowe determinanty niedoskonałości rynku nieruchomości (Real estate market imperfections: the financial determinants of), Prace Naukowe Akademii Ekonomicznej we Wrocławiu, No. 1193, pp. 289-299.

RADZEWICZ, A., RENIGIER-BIŁOZOR, M., WIŚNIEWSKI, R., 2011, From uncertainty to the efficiency of the real estate market, 18th Annual European Real Estate Society Conference in Eindhoven, the Netherlands.

RADZEWICZ A., WiŚNIEWSKI R., 2011, Niepewność rynku nieruchomości (The Uncertainty of real estate market), Studia i Materiały Towarzystwa Naukowego Nieruchomości, No. 19(1), pp. 47-57.

RATAJCZAK M., 2009, Kryzys finansowy a rozwój ekonomii jako nauki (The financial crisis and the development of economics as a science), In: Przybylska-Kapuścińska W. (Ed.). Studia z bankowości centralnej i polityki pieniężnej. Diffin, Warszawa, pp. 17-38.

RENIGIER-BIŁOZOR M., WIŚNIEWSKI R., 2012, Rating rynków nieruchomości - analiza teoretyczna (Rating of real estate markets - theoretical analysis), Studia i Materiały Towarzystwa Naukowego Nieruchomości, No. 20(2), pp. 59-70.

SMITH M.H., SMITH G., 2006, Bubble, bubble, where's the housing bubble?, Brookings Papers on Economic Activity, No. 1, pp. 1-50.

SIMON H.A., 1955, A behavioral model of rational choice, Quarterly Journal of Economics, No. 69(1), pp. 99-118.

SORDi S., VERCELLI A., 2006, Financial fragility and economic fluctuations, Journal of Economic Behavior \& Organization, No. 61(4), pp. 543-561.

STIGLiTZ J. E., 1990, Symposium on Bubbles, Journal of Economic Perspectives, No. 4(2), pp. 13-18.

STOLIŃSKA B., 2008, Rozwijająca się spirala kryzysu na amerykańskim rynku kredytów hipotecznych (A spiraling crisis on the American mortgage market), Świat nieruchomości, No. 65, pp. 10-15.

SZYSZKA A., 2009a, Behawioralne aspekty kryzysu finansowego (The financial crisis: behavioral aspects), Bank i kredyt, No. 40(4), pp. 5-30.

SZYSZKA A., 2009b, Finanse behawioralne. Nowe podejście do inwestowania na rynku kapitałowym (Behavioral finances: a new approach to investing in the capital market), Wydawnictwo Uniwersytetu Ekonomicznego w Poznaniu, Poznań.

SZYSZKA A., 2011, The genesis of the 2008 global financial crisis and challenges to the neoclassical paradigm of finance, Global Finance Journal, No. 22(3), pp. 211-216.

ŚWIERKOCKI J., 2011, Zarys ekonomii międzynarodowej (Overview of International Economics), PWE, Warszawa.

TAIPAlus K., 2006, A Global House Price Bubble? Evaluation Based on a New Rent-Price Approach. Bank of Finland Discussion Papers, 29, Helsinki, Finland.

TEDESCHI G., IORI G., GALLEGATI M., 2012, Herding effects in order driven markets: The rise and fall of gurus, Journal of Economic Behavior \& Organization, No. 81(1), pp. 82-96.

THALER R.H., SUNSTEIN C.R., 2012, Impuls. Jak podejmować właściwe decyzje dotyczace zdrowia, dobrobytu $i$ szczęścia (Nudge. How to make the right decisions about health, wealth and happiness), Zysk i S-ka, 
Poznań.

THUROW L., 1996, The future of Capitalism. How today's Forces Shape Tomorrow's Growth, New York.

TSAI I.-C., PENG C.-W., 2011, Bubbles in the Taiwan housing market: The determinants and effects, Habitat International, No. 35(2), pp. 379-390.

TYSZKA T., 1999, Psychologiczne pułapki oceniania i podejmowania decyzji (Assessing and decision making: the psychological traps of), Gdańskie Wydawnictwo Ekonomiczne, Gdańsk.

TYsZKA T., 2010, Decyzje. Perspektywa psychologiczna i ekonomiczna (Decisions: a Psychological and Economic Persepective), Łódź: Wydawnictwo Naukowe Scholar.

WILLETT T., 2010, Some lessons for economists from the financial crisis, Indian Growth and Development Review, No. 3(2), pp. 186-208.

VRIEND N.J., 1996, Rational behavior and economic theory, Journal of Economic Behavior \& Organization, No. 29(2), pp. 263-285.

WojTYNA A., 2011, Gospodarki wschodzace w obliczu kryzysu finansowego - duża odporność czy podatność? (Emerging markets in light of the financial crisis - high resistance or susceptibility?), In: Wojtyna A. (Eds.). Kryzys finansowy i jego skutki dla krajów na średnim poziomie rozwoju (The financial crisis and its impact on countries in the average level of development), PWE, Warszawa, 13-33.

WYMAN D., SELDIN M., WORZALA E., 2011, A new paradigm for real estate valuation?, Journal of Property Investment \& Finance, No. 29(4), pp. 341 - 358.

ZALEŚKIEWICZ T., 2011, Psychologia ekonomiczna (Economic psychology), PWN, Warszawa.

ZIELONKA P., 2003, Czym sa finanse behawioralne, czyli krótkie wprowadzenie do psychologii rynków finansowych (What are behavioral finances? A short introduction to the psychology of financial markets), Materiały i Studia Narodowego Banku Polskiego, 158, Warszawa. 